\title{
Gamma Radiation Sanitation of Fish and Blood Meals
}

\author{
A. VAN DER SCHAAF \\ College of Veterinary Medicine, Utrecht University, The Netherlands \\ and \\ D. A. A. MOSSEL \\ Central Institute for Nutrition and Food Research T.N.O., Utrecht, The Netherlands
}

(Received 1 February 1963)

\begin{abstract}
Trade samples of fish and blood meal containing 10-14 per cent moisture were inoculated with $0 \cdot 2-0.4 \times 10^{5} / \mathrm{g}$ of Salmonella binza and $0.2 \times 10^{6} / \mathrm{g}$ of spores of a strain of B. subtilis which had at least the same heat resistance as those of $B$. anthracis. This material was sealed in Polythene bags, filling them to the maximum, and irradiated in a $\mathrm{Co}^{60} \gamma$-cell at ca. $18^{\circ} \mathrm{C}$ with $0.50,0.75$ and $1.0 \mathrm{Mrad}$ respectively. Bacteriological examinations made ca. $72 \mathrm{hr}$ after irradiation revealed that $0.50 \mathrm{Mrad}$ secured final counts of Salm. binza below 1/25 $\mathrm{g}$ (corresponding to ca. six decimal reductions), while $1.0 \mathrm{Mrad}$ reduced viable counts of the spores used to less than $10 / g$ (i.e. four decimal reductions). The latter dose also reduced numbers of naturally present viable Lancefield group D streptococci by at least three factors of ten.

No significant losses of available lysin occurred in any of the materials at any tested dose of $\gamma$-irradiation. Autoxidative changes in the lipid fraction of the materials were noticed in fish meal only, but even there solely at dosages $\geq 0.75 \mathrm{Mrad}$ and limited to about a 100 per cent increase in peroxide value.

These results indicate that the treatment of contaminated dry products of animal origin with $\gamma$-radiation at a level up to $1 \mathrm{Mrad}$ is a promising approach to the very much required terminal sanitation of many of such products.
\end{abstract}

\section{SANITATION PAR RAYONNEMENT GAMMA DES FARINES DE POISSON ET DE SANG}

Des échantillons de commerce de farines de poisson et de sang contenant $10-14$ pour cent d'humidité furent inoculés avec $0,2-0,4 \times 10^{5} / \mathrm{g}$ de Salmonella binza et avec $0,2 \times 10^{6} / \mathrm{g}$ de spores d'une culture de $B$. subtilis lesquelles avaient au moins la même résistance à la chaleur que celles de $B$. anthracis. Ce matériel fut scélé dans des sacs de Polythène remplis au maximum, et irradié dans une cellule $\gamma-\mathrm{Co}^{60}$ à environ $18^{\circ} \mathrm{C}$. à des doses de $0,50,0,75$ et $1,0 \mathrm{Mrad}$. Les examens bactériologiques achevés environ $72 \mathrm{hr}$. après l'irradiation montrèrent que $0,50 \mathrm{Mrad}$ produisit des comptes terminaux de Salm. binza de moins de $1 / 25 \mathrm{~g}$ (ce qui correspond à environ six diminutions décimales) tandis que 1,0 Mrad diminua les comptes viables des spores utilisées à moins de $10 \mathrm{~g}$ (c'est à dire quatre diminutions décimales). Cette dose-ci diminua aussi par au moins trois facteurs de dix de nombreux streptococci Lancefield groupe $D$ viables, qui étaient naturellement présents.

Aucune perte signifiante de la lysine libre eut lieu dans aucun des matériaux à aucune dose employée de rayonnement $\gamma$. Des changements autoxydatifs dans la fraction lipide des matériaux se firent voir seulement dans la farine de poisson, et là encore seulement aux doses $\geqslant 0,75$ Mrad et limités à environ 100 pour cent d'augmentation de la valeur de peroxyde. 
Ces résultats indiquent que le traitement au rayonnement $\gamma$ à jusqu'à $1 \mathrm{Mrad}$ des produits secs d'origine animale qui seraient contaminés doit être un chemin avantageux vers la sanitation très exigée de beaucoup de tels produits.

\section{САНИТАРИЯ РЫБНЫХ И КРОВЯНЫЖ УДОБРЕНИИ $\gamma$-ОБЛУЧЕНИЕМ}

Торговые образцы рыбных и кровяных удобрений, содержащих 10-14\% влаги были инокулированы: $0,2-0,4 \times 10^{5} / г \mathrm{p}$. Salmonella binza и $0,210^{6} / г$. спор вытяжки из $B$. subtilis, которые имеют по меньшей мере такую же стойкость против нагрева, как $B$. anthracis. Этот матерьял был запечатан в пластмассовые мешки, наполненные до верху; матерьял был облучен в камере $\mathrm{Co}^{60} \gamma$, приблизительно при $18^{\circ} \mathrm{C}, 0,50,0,75$, и 1,0 Мрадами. Бактериологический анализ дал прбл. через 72 часа после облучения след. ревультаты: 0,50 Мрад дал окончательный счет Salm. binza меньше чем 1/25 гр. (соответствует прибл. уменьшению на $10^{8}$ ), тогда как 1,0 Мрад уменьшил счеты взятых жизнеспособ̆ных спор до числа меньше чем 10/гр. (т.е. уменьшил на 104). Последняя доза также уменьшила число натурально присутствующих жизнеспособных Д-стрептококов группы Лансфильд, по меньшей мере в $10^{3}$ раз. Не наблюдалось заметной потери имеющегося лизина ни в одном матерьяле ни при одной из доз $\gamma$-облучений. Самоокисление во фракции липдов было замечено только в рыбном удобрении и то только в том, которое подвергалось облучению в дозе $\geq 0,75$ Мрад и в пределах увеличения количества перекиси только примерно до $100 \%$.

Эти результаты указывают, что $\gamma$-облучение загрязненных сухих продуктов животного происхождения до предела 1,0 Мрад является обещающим методом весьма необходимой окончательной санитарии многих подобных продуктов.

\section{DESINFEKTION VON FISCH- UND BLUTMEHLEN MITTELS GAMMA-STRAHLEN}

Handelsproben von Fisch- und Blutmehl mit 10-14\% Wassergehalt wurden mit 0,2-0,4 $\times$ $10^{5} / \mathrm{g}$ Salmonella binza und $0,2 \times 10^{6} / \mathrm{g}$ Sporen einer Kultur von $B$. subtilis von mindestens derselben Thermoresistenz als die von $B$. anthracis inokuliert.

Das Material wurde in vollgefüllten Polythen Beuteln versiegelt und in einer $\mathrm{Co}^{60} \gamma$ Zelle bei ungefähr $18^{\circ} \mathrm{C}$ mit 0,5 , resp. 0,75 and $1,0 \mathrm{Mrad}$ bestrahlt.

Bakteriologische Untersuchung nach etwa 72 Stunden Bestrahlung zeigten dass 0,5 Mrad endgültige Zählungen von Salm. binza von weniger als 1/25 g ergaben was einer SalmonellaKeimzahl Verminderung von ungefähr 6 Zehnerpotenzen entspricht. Bei 1 Mrad war die Zahl lebenfähiger Sporen auf weniger als 10/g gesunken (d.h. um 4 Zehnerpotenzen).

Eine $1 \mathrm{Mrad}$ Dosis verminderte auch die Zahl züchtbarez Streptokokken der Lancefield D Gruppe um mindestens 3 Zehnerpotenzen.

Keine nennenswerten Verluste von verfugbarem Lysin fanden in irgend einem der untersuchten Materialen bei den angewanden Bestrahlungsstärken statt. Nur bei Fischmehl wurden Autoxidationsveränderungen der Lipidfraktion des Materials festgestellt bei einer Dosis $\geq 0,75$ Mrad. Der Effekt begrenzte sich auf eine $100 \%$ Erhöhung des Peroxid-Wertes.

Diese Ergebnisse zeigen dass die Behandlung von infektierten Trockenpräparaten tierischer Herkunft mit $\gamma$ Strahlen bis zu einer Höhe von 1 Mrad eine vielversprechende Möglichkeit für die so sehr benötige Endbehandlung vieler dieser Produkte darstellt.

\section{INTRODUGTION}

IN SPITE of existing and relatively well-enforced regulations, and although significant technological advances in this field have been made, yet when examining trade samples, consignments of fish, blood, meat and bone meal are frequently encountered which contain Salmonellae and similar organisms. This is no doubt chiefly due to the difficulties involved in the prevention of recontamination of already heat-treated commodities of this type. ${ }^{(1-3)}$ However, occasionally lots of these goods are still found which have only been sun-dried and are therefore apt in any case to contain Enterobacteriaceae and similar thermolabile bacteria.

This situation, which is obviously fraught with risks, can only be corrected fundamentally 
by requiring the manufacturers of such products to subject their goods to an effective terminal bactericidal treatment, i.e. pasteurization after packaging the products in impervious bags. Clearly, this can virtually only be achieved by applying $\gamma$-radiation. Also, in certain instances irradiation of dehydrated goods of this type appears not to involve impairment of the chemical composition to the extent which is invariably seen in fresh products, irradiated at room temperature.

It seemed therefore worthwhile to investigate the practical possibilities for the application of $\gamma$-irradiation to fish and blood meal for the purpose of sanitation.

\section{METHODS}

\subsection{Raw materials}

Trade samples of fish and blood meal were used in this investigation. In order to be able to evaluate the bactericidal effect of the radiation treatment in a proper way, these were artificially inoculated. Salmonella binza, recently isolated from a sample of fish meal, was used as the representative enteric organism; its attempted initial infection rate was $10^{4}-10^{5} / \mathrm{g}$ of meal. The sample of blood meal was also infected with a pasteurized culture of Bac. subtilis, producing spores with a heat resistance of the order found in the species Bac. anthracis; the spore count in the meal aimed at was again ca. $10^{5} / \mathrm{g}$.

Inoculation was carried out by first mixing in a mortar ca. $5 \mathrm{~g}$ of meal with $5 \mathrm{ml}$ of a 24 hours' culture of the strains under examination, pasteurized for $1 \mathrm{~min}$ at $80^{\circ} \mathrm{C}$ in the case of the Bac. subtilis studied. This primary mixture was then titurated with successive small amounts of meal to the level where it became an apparently dry product. This was then finally mixed with the rest of the meal so as to obtain $1 \mathrm{~kg}$ of final, inoculated product.

\subsection{Irradiation}

Samples of about $500 \mathrm{~g}$ were packed in Polythene bags $24 \mathrm{hr}$ before irradiation. These bags were filled to the maximum and then sealed. This procedure permitted some standardization of the oxygen partial pressure prevailing in the material during and after the radiation treatment.

All samples, except the controls, were irradiated in a $\mathrm{Co}^{60} \gamma$-cell with a flux of ca. $3 \times 10^{5}$ $\mathrm{rep} / \mathrm{hr}$. The dimensions of the irradiation chamber were: diameter $15 \mathrm{~cm}$, height $20 \mathrm{~cm}$.

The applied dosages were $0.50,0.75$ and 1.00 Mrad respectively, but the sample of blood meal inoculated with spores of $B$. subtilis was given only the highest dose. The temperature during irradiation was about $18^{\circ} \mathrm{C}$.

\subsection{Bacteriological examinations}

Following irradiation the samples were stored in the intact packages at $18-22^{\circ} \mathrm{C}$. All bacteriological examinations were carried out ca. $72 \mathrm{hr}$ after irradiation.

In earlier investigations it had become clear that media currently used in food and feed bacteriology yield the same recovery figures as the various special media sometimes recommended for the enumeration of viable cells, which have been subjected to sublethal doses of ionizing radiation ${ }^{(4-6)}$. Therefore standard procedures were used for the examination of the irradiated samples.

Samples were examined for Salmonellae by enriching ca. $25 \mathrm{~g}$ of material in $100 \mathrm{ml}$ of tetrathionate broth and subsequently plating onto brilliant green phenol red synthetic detergent $\operatorname{agar}^{(7)}$. This was followed by the usual biochemical (growth on and in Kligler tubes and urea agar and a lysine decarboxylase test) and serological confirmation reactions on suspect colonies.

Enterobacteriaceae were enumerated in all samples by making poured plates of violet red bile glucose agar ${ }^{(8)}$ and counting the colonies showing a purple halo on a purple background. The irradiated materials were also subjected to an enrichment test wherein samples of $10 \mathrm{~g}$ were cultured in $100 \mathrm{ml}$ buffered glucose brilliant green bile broth for $24 \mathrm{hr}$ at $37^{\circ} \mathrm{C}^{(9)}$ and thereupon streaked onto plates of violet red bile glucose agar ${ }^{(8)}$

Streptococci of Lancefield's group D were enumerated in poured plates of Packer's azide crystal violet blood agar at $37^{\circ} \mathrm{C}^{(10)}$.

Surviving spores of Bacillaceae were counted by making surface plates on infusion agar after pasteurization of the $10^{-1}$ dilutions of the 
products for one minute at $80^{\circ} \mathrm{C}$ "effective". This was carried out by heating the tubes under vigorous agitation in a boiling-water bath until the thermometer in a control tube indicates $79^{\circ} \mathrm{C}$ then transferring them rapidly to the thermostat at $80 \pm 0.2^{\circ} \mathrm{C}$ and after one minute's holding, cooling them under agitation in a water bath at ca. $15^{\circ} \mathrm{C}$. In preliminary investigations this time-temperature combination appeared to be well tolerated even by the weaker spores in a given population or among various species, while, on the other hand, virtually all non-spore bearing bacteria of common occurrence in foods are killed by this treatment.

For the purpose of obtaining an estimate of the general bacteriological condition of the samples, total aerobic and anaerobic counts of all materials were also made. For the former poured plates of infusion agar were used. Anaerobes were counted by using sulphite iron polymyxin agar contained in oval cross-section tubes and without any prior pasteurization of the dilutions to be counted in order to enumerate vegetative cells as well as spores. Among the anaerobes grown from the samples particular attention could therefore be paid to sulphitereducing clostridia ${ }^{(11)}$.

\subsection{Chemical examinations}

It was considered essential to investigate some of the nutritionally more important chemical changes which might be expected to occur in animal protein concentrates of the types studied both during and following irradiation. For this purpose all samples were stored at $18-22^{\circ} \mathrm{C}$ for at least seven days, in order to allow any radical reactions initiated by the irradiation treatments to proceed to a certain equilibrium.

The amount of available lysin was first determined in all samples, using CARpenter's technique $^{(12)}$ of coupling the free epsilon amino groups of lysin elements in the protein chain with fluorodinitrobenzene. This method of examination generally gives results which correlate very well with feeding tests.

Secondly the peroxide values of all irradiated products were determined, using chloroform/ methanol as the extraction fluid and potassium iodide in glacial acetic acid as the reagent for iodometric titration.

\section{RESULTS}

\subsection{Bacteriological aspects}

The results of all bacteriological examinations are given in Table 1.

They indicate, first of all, that up to almost six decimal reductions of Salm. binza may be achieved by dosages as low as 0.5 Mrad. These results agree with the outcome of an American investigation on the efficacy of ionizing radiation for eliminating Salmonellae from

TABLE 1. Summary of bacteriological data

\begin{tabular}{|c|c|c|c|c|c|c|c|c|}
\hline \multirow[b]{3}{*}{ Material } & \multirow[b]{3}{*}{$\begin{array}{c}\text { Dose } \\
\text { (Mrad) }\end{array}$} & \multirow{2}{*}{\multicolumn{2}{|c|}{ Enterobacteriaceae }} & \multirow{3}{*}{$\begin{array}{c}\text { Lancefield } \\
\text { D strepto- } \\
\text { cocci } \\
\text { per } 1 \mathrm{~g}\end{array}$} & \multicolumn{4}{|c|}{ Plate counts per $1 \mathrm{~g}$} \\
\hline & & & & & \multicolumn{2}{|c|}{ Aerobic } & \multicolumn{2}{|c|}{ Anaerobic } \\
\hline & & $\begin{array}{l}\text { Total } \\
\text { per } \\
1 \mathrm{~g}\end{array}$ & $\begin{array}{l}\text { Salmon- } \\
\text { ella per } \\
25 \mathrm{~g}\end{array}$ & & Total & Spores & Total & $\begin{array}{l}\text { Sulph. } \\
\text { reduc. } \\
\text { Clostr. }\end{array}$ \\
\hline \multirow{4}{*}{$\begin{array}{l}\text { Fishmeal } \\
\text { inoc. w. } \\
\text { S. binza }\end{array}$} & 0.00 & $0.2 \times 10^{5}$ & +ve & $<10$ & $0.4 \times 10^{5}$ & $0.3 \times 10^{3}$ & $0.6 \times 10^{2}$ & $0.2 \times 10^{2}$ \\
\hline & $0 \cdot 50$ & $<10^{-1}$ & -ve & $<10$ & $0.6 \times 10^{2}$ & $0.3 \times 10^{2}$ & $<10$ & $<10$ \\
\hline & 0.75 & $<10^{-1}$ & -ve & $<10$ & $0.3 \times 10^{2}$ & $<10$ & $<10$ & $<10$ \\
\hline & $1 \cdot 00$ & $<10^{-1}$ & $-\mathrm{ve}$ & $<10$ & $0.3 \times 10^{2}$ & $<10$ & $<10$ & $<10$ \\
\hline \multirow{4}{*}{$\begin{array}{c}\text { Blood meal } \\
\text { inoc. w. } \\
\text { S. binza }\end{array}$} & $0 \cdot 00$ & $0.4 \times 10^{5}$ & + ve & $0.3 \times 10^{4}$ & $0.2 \times 10^{8}$ & $0.2 \times 10^{4}$ & $0.5 \times 10^{6}$ & $0.8 \times 10^{2}$ \\
\hline & $0 \cdot 50$ & $<10^{-1}$ & $-\mathrm{ve}$ & $<10$ & $0.4 \times 10^{4}$ & $<10$ & $0.3 \times 10^{2}$ & $<10$ \\
\hline & 0.75 & $<10^{-1}$ & $\rightarrow$ ve & $<10$ & $0.3 \times 10^{3}$ & $0.3 \times 10^{2}$ & $<10$ & $<10$ \\
\hline & $1 \cdot 00$ & $<10^{-1}$ & $-\mathrm{ve}$ & $<10$ & $0.4 \times 10^{3}$ & $0.1 \times 10^{2}$ & $0.6 \times 10^{3}$ & $<10$ \\
\hline \multirow{2}{*}{$\begin{array}{l}\text { Blood meal } \\
\text { inoc. w. } \\
\text { spores of } \\
\text { B. subt. }\end{array}$} & 0.00 & $<10$ & $*$ & $0.5 \times 10^{4}$ & $0.2 \times 10^{8}$ & $0.2 \times 10^{6}$ & $0.3 \times 10^{6}$ & $0.7 \times 10^{2}$ \\
\hline & 1.00 & $<10^{-1}$ & * & $<10$ & $0.8 \times 10^{2}$ & $<10$ & $0.1 \times 10^{2}$ & $<10$ \\
\hline
\end{tabular}

* Not determined. 
dried egg products wherein it was established that seven decimal reductions could be reached with a dosage of $0.7-1.0 \mathrm{Mrad}^{(13)}$. The high bactericidal effect of the dosage tested on Lancefield group D streptococci seems also noteworthy.

Next it was established that at least four decimal reductions of Bac. subtilis spores could be effected by the application of ca. 1 Mrad. This result seems promising with regard to the possibility of applying $\gamma$-radiation to blood, bone and meat meal with the purpose of rendering them free from spores of Bac. anthracis. HORNE et al.(14) established that six decimal reductions of the most resistant spores among numerous strains of $B$. anthracis present in a dry environment, viz. goat's hair, could be achieved with $1.5 \mathrm{Mrad}$, hence that $\mathrm{D}_{\max }$ amounted to 0.25 Mrad. These data for the spores of these pathogenic bacilli agree entirely with our own figures for the spores of the strain of $B a c$. subtilis studied.

\subsection{Chemical aspects}

The results of a few tests for compounds formed in radiochemical side reactions are presented in Table 2.

In general, these figures are also quite satisfactory. In no case could any significant loss of available lysin be detected. On the contrary, an increase in the peroxide value of the lipid phase in fish meal was observed, when irradiation was at a level of $0.75 \mathrm{Mrad}$ or more. However, the increase amounted to no more than ca. 100 per cent, which is not too serious in this specific case. It could also be considerably reduced by pelletting the materials before irradiation, a procedure which is likely to be applied in future anyhow.

The results of these chemical examinations confirmed the general impression obtained when testing the colour, odour and structure of the irradiated samples in comparison with the blank since no changes whatsoever could be observed in these tentative tests.

The favourable results thus achieved in the radiation sanitation of dry goods contrast sharply to the pronounced undesired changes determined radiochemically which we have observed earlier in liquid whole egg after irradiation at $1^{\circ} \mathrm{C}$ with even significantly lower doses of $\mathrm{Co}^{60} \gamma$-rays ${ }^{(6)}$.

\section{GONGLUSION}

The treatment of packed fish, bone, meat and blood meal with $\gamma$-radiation at a level up to $1 \mathrm{Mrad}$ seems a promising approach to the terminal sanitation required in the manufacture of such produce. Both the elimination of Salmonellae and of spores of Bac. anthracis seems possible by application of such a treatment, while undesired radiochemical changes of biological significance are almost absent.

Further larger scale investigations appear therefore to be well justified. These should include more detailed microbiological examinations as a final check on bacteriological

Table 2. Summary of chemical data

\begin{tabular}{|c|c|c|c|c|c|}
\hline Material & $\begin{array}{c}\text { Dose } \\
\text { (Mrad) }\end{array}$ & $\begin{array}{c}\text { Water } \\
\text { content } \\
(\%)\end{array}$ & $\begin{array}{l}\text { Perox } \\
\text { m-equiv. } / \mathrm{kg} \\
\text { meal }\end{array}$ & $\begin{array}{l}\text { pr. as } \\
\text { m-equiv. } / \mathrm{kg} \\
\text { lipid }\end{array}$ & $\begin{array}{c}\text { Available } \\
\text { lysin } \\
(\%)\end{array}$ \\
\hline $\begin{array}{r}\text { Fishmeal } \\
\text { S. binza }\end{array}$ & $\begin{array}{l}0.00 \\
0.50 \\
0.75 \\
1.00\end{array}$ & $\begin{array}{r}10 \cdot 4 \\
10 \cdot 3 \\
10 \cdot 0 \\
9 \cdot 5\end{array}$ & $\begin{array}{l}\quad 3 \cdot 6 \\
4 \cdot 1 \\
\text { ca. } 2 \cdot 7 \\
\text { ca. } 6\end{array}$ & $\begin{array}{l}17 \\
11 \\
36 \\
41\end{array}$ & $\begin{array}{l}4 \cdot 1 \\
4 \cdot 0 \\
4 \cdot 0 \\
4 \cdot 2\end{array}$ \\
\hline $\begin{array}{l}\text { Blood meal } \\
\text { S. binza }\end{array}$ & $\begin{array}{l}0.00 \\
0.50 \\
0.75 \\
1.00\end{array}$ & $\begin{array}{l}14 \cdot 0 \\
14 \cdot 0 \\
13 \cdot 5 \\
13 \cdot 4\end{array}$ & $\begin{array}{r}<0.01 \\
0.03 \\
<0.01 \\
<0.01\end{array}$ & $\begin{array}{l}* \\
* \\
* \\
*\end{array}$ & $\begin{array}{l}5 \cdot 4 \\
5 \cdot 4 \\
5 \cdot 0 \\
5 \cdot 7\end{array}$ \\
\hline $\begin{array}{c}\text { Blood meal } \\
\text { B. subt. }\end{array}$ & $\begin{array}{l}0.00 \\
1.00\end{array}$ & $\begin{array}{l}13 \cdot 8 \\
13 \cdot 8\end{array}$ & $\begin{array}{l}<0.01 \\
<0.01\end{array}$ & $\begin{array}{l}* \\
*\end{array}$ & $\begin{array}{l}5 \cdot 2 \\
5 \cdot 5\end{array}$ \\
\hline
\end{tabular}

* Not determined.

3 
wholesomeness. Also animal feeding tests should be carried out to verify maintenance of nutritive value and absence of oral toxicity.

Acknoweledgments - The authors wish, first of all, to express their gratitude to the Directors of the Atomic Energy Research Centre at Mol, Belgium, for permission to use the irradiation facilities of that Establishment. They are also very much indebted to Dr. M. De Proost (Mol), Drs. P. Slump and H. J. Vos (Utrecht) for carrying out the dosimetric and chemical determinations reported in this paper and to Dr. F. M. HAGENS for preparing the artificially contaminated samples of fish and blood meal.

\section{REFERENCES}

1. Keil R. and Keller E. Gesundheitsw. Desinfekt. 53, 52 (1961).

2. Shotts E. B., Martin W. T. and Galton M. M. Proc. 65th Ann. Meeting U.S. Livestock Sanitary Assoc., 1961, p. 309 (1961).
3. SchaAf A. van der Tijdschr. Diergeneesk. 87, 976 (1962)

4. Davydoff S. C.R. Acad. Sci., Paris 243, 1683 (1956).

5. Freeman B. M. and Bridges B. A. Int. J. appl. Rad. Isotopes 8, 136 (1960).

6. Mosser D. A. A. Int. J. appl. Rad. Isotopes 9, 109 (1960).

7. SchaAf A. van der and JaArtsveld F. H. J. Tijdschr. Diergeneesk. 83, 345 (1958).

8. Mossel D. A. A., Mengerink W. H. J. and Scholts H. H. J. Bact. 84, 381 (1962).

9. Mossel D. A. A., Visser M. and Cornelissen A.M.R. J. appl. Bact. In press.

10. PACker R. A. J. Bact. 46, 343 (1943).

11. Mosser D. A. A. J. Sci. Fd. Agric. 10, 662 (1959).

12. Garpenter K. J. Biochem. J. 77, 604 (1960).

13. Nickerson J. T. R., Gharm S. E., Brogle R. G., Lockhart E. E., Proctor B. E. and Lineweaver H. Food Tech. 11, 159 (1957).

14. Horne T., Turner G. C. and Willis A. T. Nature, Lond. 183, 475 (1959). 